\title{
Cikkismertetés: Egészségügyi kiadások földrajzi és jövedelmi egyenlőtlenségei Magyarországon
}

\author{
Article review: Healthcare spending inequality: Evidence from \\ Hungarian administrative data
}

Ismertető: $\quad$ Bíró Anikóa $₫$, Prinz Dániel ${ }^{b}$

a: Közgazdaság-és Regionális Tudományi Kutatóközpont Közgazdaság-tudományi Intézete, Egészség és Társadalom Lendület Kutatócsoport, Budapest, b: Harvard University, Cambridge, Massachusetts

Ismertetett cikk: Bíró A, Prinz D. Healthcare spending inequality: Evidence from Hungarian administrative data. Health Policy. 2020; 124: 282-90. doi: 10.1016/j.healthpol.2020.01.006

Beküldve: $\quad$ 2020. 06. 27.

doi: $\quad$ 10.24365/ef.v61i3.609

Kulcsszavak: egészségügyi kiadások; egyenlőtlenségek; Magyarország; adminisztratív adatok

Keywords: healthcare spending; inequality; Hungary; administrative data

A Health Policy folyóiratban megjelent tanulmányunkban azt vizsgáltuk, hogyan alakulnak Magyarországon az egészségügyi kiadásokban megfigyelhető földrajzi és jövedelem szerinti egyenlőtlenségek. Vizsgálatunkhoz a magyar népesség 50\%-ára kiterjedő, a 2003-2011 közötti időszakra vonatkozó, különböző államigazgatási adatbázisokból összeillesztett adatokat használtunk. Az adatbázis - más információk mellett - egyéni szinten a bevont egyének jövedelmét, egészségügyi kiadásait, míg megyei szinten a lakóhelyükre vonatkozóan halandósági és területi fejlettségi adatokat tartalmazott. Kutatásunk fókuszában a dolgozó lakosság állt. Mintánkat leszúkítettük az aktív korú (18-55 éves) és dolgozó (minden hónapban legalább minimálbért kereső) népességre. Ezen a mintán azt vizsgáltuk, hogy miként alakultak a földrajzi különbségek az egészségügyi kiadásokban, és hogyan függ össze az adott évi egészségügyi kiadás az előző évi munkajövedelemmel. Az egészségügyi kiadások négy kategóriáját vizsgáltuk: a társadalombiztosítás által fizetett járóbetegkiadások, fekvőbeteg-kiadások, gyógyszerkiadások, illetve a gyógyszerkiadások esetében a betegek által fizetett összeg.

A tanulmány első eredménye, hogy a korábbi vizsgálatoknak megfelelően jelentős eltéréseket dokumentáltunk a különböző megyék között mind a négy egészségügyi kiadási kategóriában. A „legtöbbet költő" megyében átlagosan 77 százalékkal volt magasabb a járóbeteg-kiadás, 27 százalékkal a fekvőbeteg-kiadás és 32 százalékkal a gyógyszerkiadás, mint a „legkevesebbet költő” megyében. Öszszességében a keleti és a déli megyékben voltak legmagasabbak a kiadások, de a kiadási kategóriák részben egymástól függetlenül alakultak. 
A tanulmány második eredménye, hogy pozitív kapcsolatot találtunk a vizsgált dolgozók mintájában a munkajövedelmek és az egészségügyi kiadások között. Például a korral és nemmel korrigált járóbetegkiadás 13 százalékkal, a fekvőbeteg-kiadás 17 százalékkal, a gyógyszerkiadás pedig 11 százalékkal volt magasabb a kereseti eloszlás 75. percentilisénél (a legfelső negyed alsó határánál), mint a kereseti eloszlás 25. percentilisénél (a legalsó negyed felső határánál).

A tanulmány harmadik eredményeként azt figyeltük meg, hogy az egészségügyi kiadások és a munkajövedelmek közötti pozitív összefüggés erőssége megyénként eltérő volt. A tanulmányban megállapítjuk, hogy jelentősek voltak a megyék közötti és a megyéken belüli kiadási egyenlőtlenségek is. A részletesebb elemzés eredményei alapján megállapítható: ha a kiadásokban nem lennének különbségek a munkajövedelmi csoportok között, akkor a járóbeteg-kiadásokban kimutatott egyenlőtlenség 35 százalékkal, a fekvőbeteg-kiadások egyenlőtlensége 84 százalékkal, a gyógyszerkiadások egyenlőt- lensége pedig 77 százalékkal csökkenne. Ha viszont a megyék közötti kiadási különbségek szűnnének meg, akkor a járóbeteg-kiadások egyenlőtlensége 71 százalékkal, a fekvőbeteg-kiadások egyenlőtlensége 47 százalékkal, a gyógyszerkiadások egyenlőtlensége pedig 43 százalékkal csökkenne. Ez alapján megállapítható, hogy a fekvőbeteg-kiadások egyenlőtlensége inkább földrajzi eltérésekkel, a járóbeteg- kiadások és a gyógyszer-kiadások egyenlőtlensége inkább jövedelmi különbségekkel függ össze.

A tanulmány negyedik eredménye, hogy a korábbi vizsgálatoknak megfelelően fordított összefüggést mutattunk ki a munkajövedelem és a halandóság között. Vagyis a munkajövedelmek és az egészségügyi kiadások közötti pozitív összefüggést nem magyarázhatja, hogy a magasabb jövedelműeknek rosszabb az egészségi állapota. Ehelyett feltételezhetően a magasabb jövedelműeknek jobb a hozzáférése az egészségügyi ellátásokhoz, ezért nagyobb mértékben képesek azokat igénybe venni, de erről jelen pillanatban nem állnak rendelkezésünkre részletes adatok.

\section{TANULSÁGOK A HAZAI SZAKEMBEREK SZÁMÁRA}

Tanulmányunknak két fő tanulsága van a hazai szakemberek számára. Az első, hogy jelentősek a földrajzi és jövedelmi egyenlőtlenségek a magyar egészségügyi rendszerben. Ezért az egészségügyi rendszer fejlesztésénél érdemes odafigyelni a földrajzi és a jövedelmek szerinti egyenlőtlenségekre, illetve az egyenlő hozzáférés biztosítására a különböző régiókban élő és különböző jövedelmi helyzetű emberek számára. A második, hogy az összekapcsolt államigazgatási adatbázisokból olyan következtetéseket lehet levonni a magyar egészségügyi rendszerrel kapcsolatban, amelyeket a külön-külön aggregált adatok alapján nem. Ezért érdemes befektetni az ilyen adatbázisok létrehozásába, fejlesztésébe, hozzáférhetőségének növelésébe. 